\title{
A CHINESE STATE ENTERPRISE UNDER THE REFORMS: WHAT MODEL OF CAPITALISM?
}

\section{Anita Chan and Jonathan Unger*}

To be successfully competitive, state enterprises in China have recast themselves in the image of capitalist companies. The term "capitalist company" begs an important question, however, given that not all forms of capitalism are alike. Japanese and American-style firms, for example, take quite different approaches to many aspects of capitalist management. Our research at one state enterprise, a prosperous distillery, reveals that from the 1980s into the 2000s it instituted practices similar in many respects to the Japanese model.

The distillery's capacity to do so has depended upon its profitability. A substantial number of other state-sector manufacturing enterprises similarly have been profitable during recent decades. Much has been written about the admittedly very large number of state enterprises that could not adjust successfully to the introduction of a market economy, teetered on the brink of bankruptcy, and in the 1990s dismissed very large numbers of employees. ${ }^{1}$ Some other state enterprises, such as in the textile and footwear industries, sought to adjust by driving their long-term workforce to labor for depressed wages under

We are grateful for information provided by Chen Minghong, Ronald Dore, Cathy Walker and Wang Xiaolu.

1 See, for example, Yongshun Cai, State and Laid-off Workers in Reform China (London: Routledge, 2006); Dorothy J. Solinger, "Chinese Urban Jobs and the WTO", The China Journal, No. 49 (January 2003), pp. 61-87; Feng Chen, "Subsistence Crises, Managerial Corruption and Labor Protests in China", The China Journal, No. 44 (July 2000), pp. 4163; Feng Chen, "Industrial Restructuring and Workers' Resistance in China", Modern China, Vol. 29, No. 2 (April 2003), pp. 237-62; Ching Kwan Lee, "Pathways of Labor Insurgency", in Elizabeth Perry and Mark Selden (eds), Chinese Society: Change, Conflict and Resistance, $2^{\text {nd }}$ Edition (London: Routledge, 2000); Ching Kwan Lee, Against the Law: Labor Protests in China's Rustbelt and Sunbelt (Berkeley: University of California, 2007); Anita Chan, China's Workers Under Assault: The Exploitation of Labor in a Globalizing Economy (Armonk: M. E. Sharpe, 2001); Françoise Mengin and Jean-Louis Rocca (eds), Politics in China: Moving Frontiers (New York: Palgrave MacMillan, 2002) [chapters by Rocca, Solinger and Lee]. 
worse conditions than in previous times. ${ }^{2}$ One of the terrible downsides of the economic reforms has been this sacking and exploitation of so many millions of workers. But it is also important to study state-owned firms that have managed to prosper throughout China's economic boom ${ }^{3}$-including enterprises such as the distillery where employees have benefited.

We spent a total of four months at the distillery between 2002 and the end of 2004, during three extended research trips. It is not a "model" enterprise, and there was no effort by Chinese authorities to steer us to it. Instead, we gained access through a Chinese academic who sits on its board of directors. During the period of our stay, we were able to conduct well over a hundred unsupervised indepth interviews with five dozen of its employees, many of whom we met through our own devices. We spoke with them at length not only at the workplace but also in their homes. In May 2009 we updated our information through an interview with an employee conducted by our former research assistant and through recent articles about the distillery that are available on the web.

The distillery, which employs about 2,000 staff and workers, was founded prior to the establishment of the People's Republic, and was nationalized in the early 1950s. Distilling is an industry that relies upon heavy labor, and in both the Maoist era and today most of the employees have been only modestly educated and hold to a distinctly blue-collar identity. This is precisely the type of workforce that has fared poorly in some parts of the state-owned industrial sector during the post-Mao period of economic reform. But not here. Instead, the distillery's healthy finances have enabled it to reshape the socialist work unit (danwei 单位) experience into a relationship with employees that resembles that of large Japanese corporations. Our interviewees insisted that many of the other state-owned and former state-owned enterprises in their city's food- and drinksprocessing sector developed similar managerial practices during the reform period and have experienced similar workplace environments. It is a type of firm that has not previously been examined closely by foreign observers - a part of Chinese industrial society that warrants our attention.

2 Minghua Zhao and Theo Nichols, "Management Control of Labour in State-Owned Enterprises: Cases from the Textile Industry", The China Journal, No. 36 (July 1996), pp. 1-23; Chen Meei-Shia and Anita Chan, "China's 'Market Economics in Command': Footwear Workers' Health in Jeopardy”, International Journal of Health Services, Vol. 29, No. 4 (1999), pp. 793-811; Anita Chan and Xiaoyang Zhu, "Disciplinary Labor Regimes in Chinese Factories", Critical Asian Studies, Vol. 35, No. 4 (December 2003), pp. 559-84.

3 These include many of the most massive state corporations. Whereas most of the stateowned enterprises (SOEs) are owned by provincial, municipal and county governments, 150 or so huge companies are owned and controlled by the central state. In 2007 the combined profits of these 150 behemoth companies totaled a trillion yuan (US\$140 billion), a rise in profits of 223 per cent compared to just five years earlier when they were already doing very well. George Dyer and Richard McGregor, "China's Champions", Financial Times, 16 March 2008. 


\section{Variants of Capitalism: Neo-liberal vs. Organization-Oriented}

Several comparative scholars have focused attention on the differences between two capitalist industrial models-market-oriented neo-liberal capitalism, exemplified by the United States and Britain, and a non-neoliberal, organizationoriented capitalism, exemplified by Japan and Germany. ${ }^{4}$ It has been argued that corporate governance, sources of finance, management styles, remuneration systems, hirings and firings, the trade unions' relations with management, and the "corporate culture" of firms all differ between these two models.

In the Anglo-American model the enterprise looks more toward the enterprise's share-market price, and accordingly tries to boost short-term profits, with a stress on accountability to shareholders, while preferring to treat the workforce in terms of a free labor market. The individual employee theoretically decides regularly whether to be on the move, seeking the highest price for his or her skill; and management cautiously weighs the returns from its training costs, knowing that an employee may well depart. Neither side feels particularly obliged to the other beyond the labor contract.

In Japan and Germany, enterprises are relatively insulated from the stock market's influence due to reliance on bank-based financing, allowing firms to focus on more long-range goals. Because firms in Japan and Germany are less beholden to stock market sentiment than in the American or British systems, they have a greater tendency to retain and reinvest profits, rather than distribute substantial dividends.

Thinking more in the longer term, the large Japanese and German firms are considerably more inclined to provide employees with job security and a career pattern based on seniority. ${ }^{5}$ One consequence is that the enterprise provides

4 See, for example, Ronald Dore, British Factory-Japanese Factory: The Origins of National Diversity in Industrial Relations (London: Allen and Unwin, 1973); Ronald Dore, Taking Japan Seriously (London: The Athlone Press, 1987); Ronald Dore, Stock Market Capitalism, Welfare Capitalism: Japan and Germany versus the Anglo-Saxons (Oxford: Oxford University Press, 2000); Wolfgang Streeck and Kozo Yamamura (eds), The Origins of Nonliberal Capitalism: Germany and Japan in Comparison (Ithaca: Cornell University Press, 2001); Kozo Yamamura and Wolfgang Streeck (eds), The End of Diversity? Prospects for German and Japanese Capitalism (Ithaca: Cornell University Press, 2003); Peter A. Hall and David Soskice (eds), Varieties of Capitalism: The Institutional Foundation of Comparative Advantage (New York: Oxford University Press, 2001); Kathleen Thelen, How Institutions Evolve: The Political Economy of Skills in Germany, Britain, the United States, and Japan (Cambridge: Cambridge University Press, 2005).

5 Some writers have emphasized that the Japanese model does not apply to much of Japanese industry, especially among smaller firms (Jon Woronoff, Japan as Anything but Number One (Armonk: M. E. Sharpe, 1990). Even during the heyday of the Japanese model, only about a third of Japan's workforce, the core workers in large firms, actually enjoyed lifetime employment (Akira Takanashi, "Japan's High Economic Growth and Industrial Relations", in Bert Edstrom [ed.], Industrial Relations, Wages and Employment in the Japanese Labor Market [Stockholm: The Centre for Pacific Asian Studies, 1994]). 
extensive in-house training and apprenticeships in the expectation that employees will not subsequently move to other firms. ${ }^{6}$

Especially in Japan, the employees' long-term working career is taken directly into account in remuneration packages. In Japan's large core enterprises, employees are not paid only according to their skill levels, but also in accord with criteria such as age and years of service. When compared to the Anglo-American model, this results in a relatively small gap in wages among employees of the same age and length of service. It also encourages a long-term paternalism that manifests itself, famously in Japan, in non-monetary benefits. Such benefits have included subsidized housing that creates enterprise-centered communities. Especially in the heyday of the Japanese system in the 1960s-80s, employee perquisites also included "welfare benefits paid ... for transportation, canteen and other food services, medical, purchasing, and cultural and recreational facilities".

To ensure that job security in a core enterprise can be guaranteed, the firm employs a corps of temporary workers, and they are the ones who get laid off during a business downturn instead of the permanent workforce. Also, commonly, part of the production gets subcontracted to small peripheral companies, and during downturns this production gets pulled back into the main firm to keep its otherwise excess employees occupied.

These attributes of large Japanese firms continue to be witnessed during the crisis in the world economy that began in 2008. According to The Financial Times:

Instead of mass layoffs or cuts in facilities, companies in Japan are cutting part-time staff. (Layoffs of full-time workers remain taboo.) They are also delaying or cancelling fewer new factories than elsewhere. One reason is that Japanese companies have war chests of cash built up during Japan's recovery earlier this decade. Another is that, unlike in the United States, shareholders lack the power to demand that cash be paid out as dividends. $^{8}$

Given the mutual commitment to lifelong employment in the same enterprise, a Japanese enterprise in the core sector is envisioned as a community or, as the Japanese have often put it, as a company "family". 9 An effort is made to seem

For the majority of the Japanese workforce not in the core sector, the rate of job-mobility was about the same as in other industrialized countries. Solomon B. Levine, "Careers and Mobility in Japan's Labor Markets", in David W. Plath (ed.), Work and Lifecourse in Japan (Albany: State University of New York Press, 1983), pp. 15-33.

6 Kathleen Thelen, How Institutions Evolve.

7 Robert E. Cole, Japanese Blue Collar: The Changing Tradition (Berkeley: University of California Press, 1971), p. 73.

8 The Financial Times, 12 December 2008, p. 12.

9 Rodney Clark, "The Company as Family: Historical Background", in Daniel Okimoto and Thomas Rohlen (eds), Inside the Japanese System (Stanford: Stanford University Press, 1988), pp. 103-05. 
communal: supervisors and workers wear the same work clothes and share the same canteens at lunch. This ethos of an enterprise community is shared even by top executives. As noted by the Japan specialist Ronald Dore, "in Japanese firms ... nobody gives a great deal of thought to owners ... The president, the vice-presidents, and the large Board are treated as, and see themselves as, the elders of the enterprise community. Their primary concern is the reputation of the community and the welfare of its members ..." All in all, it is not surprising that the Japanese firm supports a more consensual system of labor-management relations, compared to a more adversarial labor-relations system in the AngloAmerican neo-liberal model.

Ronald Dore has drawn up a list showing the key attributes of an ideal-type Japanese enterprise as opposed to the attributes of an Anglo-American firm: ${ }^{11}$

\begin{tabular}{|l|l|}
\hline Japanese & Anglo-American \\
\hline Organization-oriented & Market-oriented \\
\hline Communitarian & Individualistic \\
\hline The firm as entity & The firm as instrument \\
\hline Quasi-community firm & Company-law-conforming firm \\
\hline The firm as an aggregation of people & The firm as a nexus of contracts \\
\hline Jinponshugiteki (human-capital-ist) & Shihonshugiteki (money-capital-ist) \\
\hline Enduring relational transactions & Limited contractual transactions \\
\hline Employee-sovereignty & Shareholder-sovereignty \\
\hline Appealing to membership motivation & Appealing to market motivation \\
\hline
\end{tabular}

The scholars who study the contrasting Japanese-German and AngloAmerican capitalist systems have focused on the lock-in and path dependency effects of the countries' prior developmental histories. Germany and Japan evolved out of political systems going back to the $19^{\text {th }}$ century that were not liberal democracies. The states played a strong hand in economic development. Historically, Japan had consciously learned from the Germans. At each critical juncture in their histories, both systems adapted to new political and economic conditions, but always building on their existing institutional arrangements, accommodating the demands of labor in exchange for cooperation. War mobilizations particularly required a corporatist system. After World War II both countries came under American occupation, but they were still able to emerge with their industrial systems largely intact. For instance, the origin of today's German institution of co-determination at the workplace between management and the works council can be traced to 1891 when workers' committees

10 Ronald Dore, Stock Market Capitalism, pp. 25-26. For a somewhat different, less sanguine view of the Japanese model, see Andrew Gordon, The Wages of Affluence: Labor and Management in Postwar Japan (Cambridge MA: Harvard University Press, 1998).

11 Ronald Dore, "Innovation for Whom?", in Rene Haak and Markus Pudelko (eds), Japanese Management: In Search of a New Balance Between Continuity and Change (Houndmills: Palgrave, 2005). 
(Arbeiterausschüsse) with limited consultation rights were legally institutionalized. $^{12}$ In Japan, what is known as the Japanese labor-management consultation system (roshi kuyogi-sei) was introduced in the 1920s and survived. ${ }^{13}$ Today, it is equivalent to a much weaker version of the German works council. In any event, the idea of consultation prevails in both of these national forms of organization-oriented capitalism.

While the Japanese and German forms have distinct similarities they also exhibit distinctive differences. In Germany the national industrial unions are much better developed and collective bargaining often occurs at the regional level, and the welfare system is largely coordinated and administered at the national level. In Japan, collective bargaining takes place at the enterprise level, and the enterprise normally takes care of workers' welfare. Looking back in time, historically the catch-up mentality of Japanese developmentalism encouraged a strong state to work in cooperation with capital and labor by way of a more enterprise-oriented system, with its attendant enterprise trade unionism, enterprise welfare-ism, and an enterprise envisioned in terms of a family or as a community.

In the pages that follow, it will be seen that the Chinese state enterprise that we have studied more closely resembles the Japanese than the German example. Consequently, we will largely make references to Japan rather than Germany when discussing whether the distillery's operations can be said to fall under the umbrella of organization-oriented capitalism.

\section{The Maoist Work Unit (Danwei) State-Oriented System}

In light of the fact that path-dependency effects have strongly influenced how the modern Japanese and German industrial systems operate, if we are to understand the course taken by the Chinese distillery during the post-Mao era we must first look back at its antecedent. What were the overall attributes of the Maoist industrial system and what circumstances prevailed at the distillery?

The emergence of the Maoist system in the 1950s was itself the result of pathdependent development based on industrial arrangements that arose during the Republican era under the Nationalist government. In the 1920s and 1930s, a newly established legal framework for industrial relations, along with statecorporatist tendencies, heavy-handed state intervention, and paternalistic practices to curb a high labor turnover rate among skilled workers helped lay down the

12 Gregory Jackson, "The Origins of Nonliberal Corporate Governance in Germany and Japan", in Wolfgang Streeck and Kozo Yamamura (eds), The Origins of Nonliberal Capitalism, p. 150.

13 S. J. Park, "Labour-Management Consultation as a Japanese Type of Participation: An International Comparison", in Jokunago Shigeyoshi and Joachim Bergmann (eds), Industrial Relations in Transition: The Case of Japan and the Federal Republic of Germany (Tokyo: University of Tokyo Press, 1984), pp. 153-67. 
preconditions for the socialist workplace (danwei) system. ${ }^{14}$ This was similar to Japan, where the modern industrial corporations of the Meiji era in the late $19^{\text {th }}$ century provided housing and other perquisites to employees whose skills were in short supply, in order to induce them to remain with the firm over the long term.

After the Communist Party came to power and nationalized factories in the 1950s, it first endeavored to install a Soviet-style wage system based on skill rankings and output quotas, but soon reverted to a work-year seniority system, in part reflecting the expectations and pressures of older workers. ${ }^{15}$ The Chinese socialist danwei became not only a workplace but an all-encompassing work and residence community, which provided for the employees' families' everyday needs, pensions, jobs for employees' children and so on. The enterprise trade union did not have any actual trade-union function, but rather served as the welfare department of management. Many aspects of this system resembled the Japanese system: practically no job mobility between firms, in-house training programs, wages based on a work-year seniority system, life-time employment security, the workplace serving as a community (including provision of accommodation) and so forth.

Maoism espoused egalitarianism. With frugality and conformity imposed, everyone wore basically the same, ubiquitous, dull-colored garb. Facilities tended to be single-status, the pay system was monthly for all, and the distinction between staff and workers in a factory was not visibly marked. In government statistics, managers, office staff and blue-collar workers were (and still are) almost always referred to as zhigong (职工, staffworkers as one word), as if they were all one single category of working people, fudging the boundary between the groups.

In some respects the Maoist industrial system possessed the features of a war economy, similar to Japan during World War II: planned, authoritarian, nationalistic and collectivistic. Individuals were asked to sacrifice for the common national cause during speed-up-production mass mobilization campaigns that swept the nation one after another. ${ }^{16}$

14 Mark W. Frazier, The Making of the Chinese Industrial Workplace: State, Revolution, and Labor Management (Cambridge: Cambridge University Press, 2002); Morris L. Bian, The Making of the State Enterprise System in Modern China (Cambridge MA: Harvard University Press, 2005).

15 Mark W. Frazier, "Commanding Heights: Industrialization and Wage Discrimination in the Chinese Factory, 1950-1957", in Jacob Eyferth (ed.), How China Works: Perspectives on the Twentieth-Century Industrial Workplace (London: Routledge, 2003); William Brugger, Democracy and Organisation in the Chinese Industrial Enterprise, 1948-1953 (Cambridge: Cambridge University Press, 1976).

16 Barry M. Richman, Industrial Society in Communist China (New York: Random House, 1969), pp. 223-364; Andrew G. Walder, Communist Neo-Traditionalism: Work and Authority in Chinese Industry (Berkeley: University of California Press, 1986), pp. 113-22. 
This Mao-era danwei system was not an "organization-oriented" system as exists in modern-day Japan or Germany. Rather, the Maoist industrial system was "state-oriented", in that the socialist economy was centrally planned, with centrally-planned employment and remuneration systems. Neither the market nor the enterprise, but instead the Chinese state, became the ultimate decision-maker in the allocation of resources and living standards. This meant that employees could not look to the enterprise and its commercial success as the source of their welfare. Instead, their welfare explicitly depended upon state policy.

In addition, the object of employee identification was different: it involved demands for loyalty to the Party-state, not to the enterprise organization. Whereas Japanese enterprises often have their own anthems, Chinese danweis sang songs of devotion to Chairman Mao. The distinction is an important one. In post-World War II Japan, the collective welfare of the enterprise has taken precedence over those of the state and the individual. (This is not "culturally" bound: in the preWorld War II period, the interest of the state, personified in the Japanese emperor, prevailed over all other interests.) In Mao-era China, the highest levels of the polity went to great lengths to have all attention and loyalty directed toward the overriding will of the Party-state and, at the height of Mao's personality cult, the will of the deified leader. The political system manufactured pejorative labels such as "individualism" and "economism" (a term that was used to decry the danwei taking its own initiative to grant workers higher pay and greater benefits than the Party-state sanctioned). At the height of political campaigns, these labels could invite political penalties and purges. Political control was one of the danwei's functions, and as a result the Maoist workplace did not enjoy harmonious relations but instead bred mutual suspicion and mistrust. ${ }^{17}$ Under such circumstances the Maoist danwei squandered opportunities to play a cohesive social role similar to the Japanese workplace.

The distillery exemplified this pattern. In the Maoist period, its workforce suffered from a level of poverty that was imposed by state policy. Government regulations stipulated that the employees at different types of factories received different levels of benefits, and the distillery, as a city-level enterprise under the supervision of the lowly foodstuffs bureau, sat low on the administrative ladder. It also used very old-fashioned, labor-intensive liquor-making methods, and in the Marxist worldview this type of work did not have the prestige of modern heavy industry. Thus, during the period of Mao's rule, government policy directed that the distillery's salaries and perquisites were to be set at a noticeably poorer level than in high-status, prioritized industries such as steel production. Elderly

17 The divisive tensions engendered by the political controls exploded in the Cultural Revolution turmoil of 1966-68 into violence between employees in many of China's factories (though not at the distillery). On these tensions, which preceded the Cultural Revolution and re-emerged at factories when the Party's controls were reintroduced in the 1970s, see Jonathan Unger, "The Cultural Revolution at the Grass Roots", The China Journal, No. 57 (January 2007), pp. 123-27. 
interviewees recall subsistence living standards and extremely crowded and rundown enterprise housing. Three generations of a family crammed into one or two small, dank rooms, without any kitchen space or nearby tap water. But our elderly interviewees say that at the time they had not felt disgruntled or disillusioned, since many of them could remember an even more impoverished standard of living before Communist rule. Though their daily lives were difficult, their basic needs were met through food and cloth rations, they enjoyed job security and could look forward to modest pensions. Throughout, they largely accepted the new Party-led system. Nevertheless, the workers became discomforted by neverending rounds of "political study" and by a succession of campaigns that often puzzled them, sometimes worried them, very frequently bored them, and only occasionally aroused any enthusiasm. Notably, in all of these political-study sessions and campaigns, what was supposed to inspire conscientious work was not loyalty to the distillery but rather devotion to the national revolution and Party.

In line with Maoist ideology, within the distillery an egalitarian ethos prevailed in terms both of salary patterns and the distinction between blue- and white-collar work. A retired technician recalls,

In the 1970 s, the distillery director had to labor for at least one month each year ... The shopfloor head was considered like an ordinary worker in the sense that everyone labored. Later, under Deng, when the shopfloor head and the foremen stopped doing manual work it was a big change in status ... There was a sense of everyone being almost the same materially [under Mao], since their wages were about the same. The monthly bonus was no more than a few yuan. The shopfloor head got 4 yuan. Those who got the least had 3 yuan.

In these respects, even if driven by ideological reasons, the distillery under Mao maintained practices somewhat similar to those of Japanese enterprises. As noted in a well-known study of the 1970s on the workforces of large Japanese companies, "An almost universal feeling among the workers in the [Japanese] shop was that foremen were workers and not management representatives ... This view was strengthened further in the postwar period with the spread of egalitarian values and the reduction of wage differentials". ${ }^{18}$

\section{The Post-Mao, Organization-Oriented System at the Distillery}

Under the command economy of Mao's time, the distillery leaders had to focus on meeting the targets of the Party-state and the foodstuffs bureau, and they had almost no scope to be benefactors of their workforce, since they had no leeway to decide on the salary scale and living conditions. But after Mao's death, under the economic reforms of Deng Xiaoping, this changed.

Starting in the 1980s, there was no longer Maoist-style political study or strong political controls over the managers and workforce, and the distillery

18 Robert E. Cole, Japanese Blue Collar, p. 186. 
managers were no longer under strong command-economy pressures to serve the interests of the state. Reforms to industry in the 1980s allowed enterprises to retain much of their profits and gave far greater discretion to management on how to spend the funds. The distillery benefited greatly from this. At that time, officials throughout China were increasingly lavish with expensive liquor when banqueting at public expense, and the distillery was permitted to sell its output at high market prices. Many blue-collar employees (including the foremen) felt that a debt was owed to them. They believed that, since they had put in many years of loyal service in poverty, the distillery leadership was in turn duty-bound to be paternalistic and to share out the enterprise's new-found profits. ${ }^{19}$ The management agreed. The distillery began to morph into a decidedly organizationoriented enterprise, in which loyalties and corporate strategies were focused not on a controlling state but rather on the welfare of the organization's membership. Ronald Dore's description of the Japanese system quoted earlier in this paper came to fit the distillery: under the new economic dispensation, the heads of the distillery saw themselves (borrowing Dore's words) as the paternalistic "elders of the enterprise community" and "their primary concern was for the reputation of the community and the welfare of its members". They were amenable to putting in place a series of policies that greatly favored the employees' interests. This was a widespread phenomenon in China in the 1980s. As a recent study observes, "it became the common expectation that managers would secure the retained funds and use them to upgrade workers' living standards. The better they fulfilled the expectation, the more legitimacy and popularity they would gain as danwei leaders". ${ }^{20}$

\section{Bestowal of benefits}

With no pressures to provide dividends to any "owners", the distillery used a good part of its after-tax profits to expand greatly the range of benefits available to employees up into the 2000s. Although employees' salaries were not at all high, at less than 2,000 yuan a month in the early 2000s, this was supplemented by a stream of monetary and non-monetary benefits. For instance, the distillery bestowed gifts and extra money on them at all national holidays, as well as a gift at the end of the year of some 800 yuan in cash, disbursed equally to each employee. The company's generosity in the early 2000s also extended to full

19 On the background to this attitude at the distillery, see Jonathan Unger and Anita Chan, "Memories and the Moral Economy of a State-Owned Enterprise", in Ching Kwan Lee and Guobin Yang (eds), Re-envisioning the Chinese Revolution: The Politics and Poetics of Collective Memories in Reform China (Washington: Woodrow Wilson Center Press; Stanford: Stanford University Press, 2007), pp. 119-40.

20 Yu Xie and Xiaogang Wu, "Danwei Profitability and Earnings Inequality in Urban China", The China Quarterly, No. 195 (September 2008), p. 566. Also see Andrew G. Walder, "Factory and Manager in an Age of Reform", The China Quarterly, No. 118 (June 1989), pp. 249, 251. 
medical coverage (the enterprise even paid 100,000 yuan to cover kidney transplants for two employees) and free life insurance. There was also a wide range of other perquisites large and small (a range even broader than the Japanese system in its heyday). These included a small heating subsidy every year for each distillery employee's household (a carry-over from Mao's day), a generous lunch subsidy in cash, and a subsidy for "reading materials". The diverse monetary and non-monetary benefits have enabled employees to accumulate savings, and thus they could begin to make major purchases. As of 2003-04, an issue at the enterprise's housing estates was a shortage of parking spaces. Even some of the blue-collar families were pooling the earnings of several family members to purchase cars.

In the Anglo-American system, the level of remuneration across different companies in the same industry is similar for a given level of skills, as determined by the labor market (and whether there is a union at the workplace). Workers are not expected to have a claim on profits: a blue-collar employee of a profitable firm does not earn twice what a similar worker in a less-profitable firm earns. Not so in China today, where "workers who are employed in a highly profitable danwei earn as much as 2.5 times those who are otherwise comparable but employed in a relatively unprofitable danwei". ${ }^{21}$

This same distinction extends to retirees. In light of the distillery's career-long employment of staff and its self-image as a paternalistic family, the enterprise management's sense of responsibility extended to showing benevolence toward retirees, as much as to its current workforce. Retirees were entitled to many of the same gifts and subsidies. During the period of our research, all of the retirees were feted by the distillery head at a restaurant banquet, at which the leader thanked them for the years of hard work they had given to the enterprise. When we were at the distillery in 2003, the retirees were ceremoniously each handed a red envelope at the banquet containing a New Year gift of 300 yuan, along with apologies that the amount was 100 yuan less than the previous year, which had been more profitable for the company. In another show of appreciation, all of the retirees and their spouses were given free overnight sightseeing tours every year to famous scenic landmarks.

The enterprise was not an anomaly among state enterprises in providing such benefits. Interviewees said that many of the other state-owned enterprises in their city's food-processing industry have sought to look after the interests of both their workforce and retirees in a similarly paternalistic fashion.

Good housing has stood near the top of employees' wish lists. The distillery responded in the mid-1990s by constructing two large housing developments containing very decent apartments, which were sold off to the workforce at a large discount. In line with the enterprise's stress on work-year seniority, those who had served the distillery the longest were given the first pick of apartments, and

${ }^{21}$ Yu Xie and Xiaogang Wu, "Danwei Profitability and Earnings Inequality”, p. 579. 
were offered a 2 per cent reduction below the cost of construction for every year they had worked there. The greatest beneficiaries were largely older blue-collar workers. Some of them, with 40 years of work under their belts, obtained large apartments for only 20 per cent of the construction cost. ${ }^{22}$ The managers and workers lived together in these new housing estates: that is, in a tight-knit enterprise residential community. A nursery school and kindergarten were provided there at company expense. The distillery also undertook to construct a small building at the housing compounds to house a retirees' social club, and covered all of the running costs. As in Japan, the enterprise's responsibilities have extended outside work hours and well beyond the factory premises.

The enterprise trade union organized the retirees' social club and dispensed many of the other benefits on behalf of the distillery. In Japan, too, the union has been "closely integrated into company administration". ${ }^{23}$ A difference is that in Japan the union also normally serves genuine functions of worker representation. At the distillery, in contrast, the enterprise union officials are all appointed by management, and the heads of the production workshops sometimes serve concurrently as the union officers. One such dual-role occupant explained to us her union responsibility: "It involves paying attention to who has hardships and going to help them with money or going to hospital to visit them". The deputy director of the distillery union even observed that "when couples have a marital problem we come in to mediate".

Alongside the union's solicitous welfare function, the distillery's managers were personally expected to regularly undertake duties to express their own paternalistic concern. While a union officer helped to organize funerals on behalf of grieving families, the top managers took the lead in performing a formal mourning role as heads of the enterprise family. During the period we were conducting research at the distillery, one of the young salesmen died in a car crash, and the deputy head of the union noted:

22 Jonathan Unger and Anita Chan, "The Internal Politics of an Urban Chinese Work Community: A Case Study of Employee Influence on Decision-Making at a State Owned Factory”, The China Journal, No. 52 (July 2004), pp. 1-24. The distillery was not alone in this. A recent book which praises Wuhan Steel (Wugang) for its profitable corporate reform initiatives observes that in 1998, "Wugang started an aggressive project to develop a self-contained landscaped complex with 10,000 apartment units for its workers. When the project was completed in 2002, the units were apparently sold to employees at cost; that is, at about one-third to half of the market value. Wugang also provided some longservice employees with additional discounts ... For those employees who rented units, they were charged similarly at about one-third of the market rate, with the rental agreement continuing into retirement (p. 187) ... In the minds of Wugang's managers, providing adequate social welfare appears to remain a priority" (p. 190). John Hassard, Jackie Sheehan, Meixiang Zhou, Jan Terpstra-Tong and Jonathan Morris, Chinese State Enterprise Reform: From Marx to the Market (London: Routledge, 2007), italics added.

23 Robert E. Cole, Japanese Blue Collar, p. 98. 
All of the members of the top leadership will go to the funeral. All of them. The family will be terribly moved by this. And people in the sales department get to see how the leadership cares, and this makes them feel good and it increases their work incentive ... Our factory is very good in taking care of deaths. Each one gets burial expenses averaging some 10,000 yuan. The amount we give varies with length of service.

The notion that a manager's duties include solicitous attendance at employees' funerals will be familiar to Japan specialists.

\section{Life-time employment, in-house training and work-year pay}

As in Japan and Germany, an enterprise like the distillery maintains a special relationship with a bank and relies upon bank loans for much of its long-term investments, to a far greater extent than in America or Britain. This reliance on banks is commonplace today. A 2008 article observes, "Japan and Germany rely mostly on bank finance for corporate financing needs, whereas Anglo-Saxon countries resort to markets ... The Chinese financial system ... can be characterized as bank-oriented". ${ }^{24}$ In addition, with less concern about stockmarket prices and less worry about providing a regular high stream of dividend distributions, there has often been a high rate of reinvestment of profits, looking to the longer term. Both of these phenomena were evident at the distillery during the period of our research.

Parallel to this focus, the distillery, as in Japan and Germany, presumed that employees would spend their careers within the firm. Also similar to Japan and Germany, this has provided the basis for an extensive program of in-house job training. This had been the case during the Maoist period, when a traditional apprenticeship system was retained at the distillery, and it remained the case in the early 2000s. Young blue-collar recruits still learned the trade as apprentices for three years under a "master" (shifu) worker, all the while earning only partial pay. In 2004 one of the workers observed, "When the apprentice graduates, he has to invite all his workmates for a good meal at which it's formally recognized he's been brought up by the master worker". It cements a life-long formal bond, recelebrated each year at Chinese New Year and on the master worker's birthday, when all his former apprentices visit his home bearing small gifts. The distillery, in short, retains an organizational framework for job training that mimics fatherson relationships within the enterprise "family".

Similar to Japan, as of the first half of the 2000 decade wages and bonuses at the distillery rewarded (i) length of service and promoted (ii) egalitarianism and (iii) work-group solidarity. To a degree that is truly extraordinary by international standards, in all three of these aspects the principle got carried out far beyond

24 Yasushi Suzuki, Md. Dulal Miah and Jinyi Yuan, "China's Non-Performing Loan Crisis: The Role of Economic Rents", Asia-Pacific Economic Literature, Vol. 22, No. 1 (May 2008), p. 57. 
what occurs in the Japanese wage system. A woman in late middle age observed to us in 2003 ,

I'm now considered a managerial cadre, but my income is about the same as an ordinary worker who entered the distillery at about the same time I did. University graduates who entered more recently don't have as high an income, and they earn only a few tens of yuan more per month than the workers who arrived at the same time as themselves. My own base wage now is about 600 yuan, which is 80 to 90 yuan higher than someone who's been here five years. We also all get a monthly bonus, which is the largest component of my income. It varies according to the distillery's profits. Mine comes to about 800-900 yuan a month, and sometimes over 1000 yuan. I work in an administrative department, so my bonus amounts to exactly 80 per cent of the average of the blue-collar workshop workers' bonus. A workshop head's is 1.2 times one of his worker's, up to the top for a manager, who gets a bonus that's 1.3 times a worker's. But if we privatize, the gap is sure to widen.

Though this payment system may seem in line with Maoist ideology-with blue-collar workers, for instance, earning as much as or more than this managerial cadre - the system was not a direct carryover from Maoist times. In fact, in the earlier period of economic reforms in the 1980s and early 1990s, the remuneration and bonus systems at the distillery rewarded rank and effort more than in the first half of the 2000s. This can be seen in both the annual and monthly bonuses. Earlier, in the 1980s and early 1990s, the large annual bonus provided at the Chinese New Year varied according to the level of an employee's post, but by the early 2000 s every distillery employee received precisely the same amount. So, too, all of the workers in the same workshop came to receive exactly the same amount as their mates as a monthly bonus, even though the bonus initially was supposed to serve as an individual incentive system. A workshop head told us in 2003, "Today, these monthly bonuses are basically a case of 'everyone eating from the big rice pot' (da guo fan 大锅饭), whereas earlier there was a distinction made as to how much you worked". The pressures and ethos from within the work community had had a leveling effect, more so than in Japan. The components in the remuneration package, though, were similar to Japan's. The wage systems in both Japan and an enterprise such as the distillery contained a base-wage component tied to work-year seniority, ${ }^{25}$ plus a substantial bonus system for all employees. $^{26}$

25 For the first two decades after World War II, the Japanese wage structure was very strongly work-year related. A job-level supplement in the Japanese system was a more recent innovation of the Sixties. Bernard Karsh and Robert E. Cole, "Industrialization and the Convergence Hypothesis: Some Aspects of Contemporary Japan", Journal of Social Issues, Vol. 24, No. 4 (1968), pp. 45-63; Ronald Dore, British Factory-Japanese Factory, p. 104.

26 In the Japanese system, during the 1970s a semi-annual bonus in large firms comprised 26 per cent of the year's income, rising to an average for all firms of 35 per cent in 1990 
Much as in Maoist times, in the early 2000s the distillery's commitment to employees extended to their families, and so the distillery gave priority to hiring the children of employees. Only if there were not enough qualified applicants from among the children did the company recruit new workers from outside.

The distillery's prestige brands sell well - at up to 1,000 yuan (US\$180) a bottle for the very finest - and thus the enterprise runs at a profit. But starting in the late 1990s the market for cheaper liquors began suffering and production had to be cut back. As a consequence the distillery was now employing a larger workforce than it needed. Yet as of $2002-03$ no one had been laid off, ${ }^{27}$ in an enterprise commitment to try to maintain lifetime employment, and the levels of the blue-collar employees' salaries were all maintained. The enterprise began adjusting to the downturn through a strategy of investing in new product lines, such as plans to produce plum wines, rather than downsizing. The distillery, like a core Japanese firm, also had two other ways to retain full employment for its permanent staff. First, during the prior period of boom demand for inexpensive liquor, the distillery had begun sub-contracting production to nearby external suppliers rather than attempt to expand its own production rapidly. It thus could choose to stop orders when the market demand for liquor contracted, while retaining the production at its own distillery. Second, again akin to Japan's core firms, the distillery hired a group of temporary workers from the countryside during the boom years of the 1990s, who could be let go during periods of contraction. This latter strategy, however, became intertwined with the distillery's desire to provide employment to the kin of its permanent workforce. All of the hundreds of temporary workers who got hired were rural relatives of employeescousins and second cousins - and by the early 1990s they had been there long enough to seem like semi-members of the corporate community. The distillery ethos made it unseemly to dismiss them, and so they continued to labor in the

(Kazutoshi Koshiro, "Development of Collective Bargaining in Post-War Japan", in T. Shirai [ed.], Contemporary Industrial Relations in Japan [Madison: University of Wisconsin Press, 1983], pp. 205-57; Richard Curtain, "Recent Developments in Human Resource Management Practices in Japanese Enterprises" [unpublished manuscript, Canberra, Australia, 1993]). Robert E. Cole notes, "In the past, the semi-annual bonuses were viewed as a sign of management generosity and paternalism", but by the 1960s workers considered it "not a gift but a right to which they were entitled" (Japanese Blue Collar, p. 176).

27 A statistical analysis of a survey of state enterprises, conducted by Jean Oi up through 2004, showed that a majority of the enterprises that restructured have also been averse to laying off workers. (Our thanks to Jean Oi for this information.) Other findings from her survey are discussed in Jean Oi, "Patterns of Corporate Restructuring in China: Political Constraints on Privatization", The China Journal, No. 53 (January 2005), pp. 115-36. In a vein similar to the distillery, a study of profitable Wuhan Steel (Wugang) notes that surplus workers retained their employment by being placed into subsidiary non-steel enterprises which Wugang established. As a result, "overall, there have been relatively few direct lay-offs over the years at Wugang". John Hassard, Jackie Sheehan, Meixiang Zhou, Jan Terpstra-Tong and Jonathan Morris, Chinese State Enterprise Reform, p. 187. 
workshops eight hours a day at full pay. The astonishing result was that, during the 2001-03 downturn, the permanent workers who produced the cheaper brands of liquor were given a much-reduced workload and were told to come to work for only four hours a day or alternatively, to save them the effort of commuting, to come to work only every second day - at full pay.

\section{Workplace Consultation}

State-owned enterprises are all supposed to have Staff and Workers Representative Congresses (Zhigong daibiao dahui 职工代表大会), which are somewhat similar in form to works councils in Germany and Japan. The Chinese congress and its legally-sanctioned representation on the supervisory board of publicly owned firms goes against the thrust of the Anglo-American shareholderoriented model, and is instead in line with the organization-oriented framework.

The staff and workers' congresses derive historically from the workers' councils of the Soviet Union and Eastern Europe. The best-known of the workers' councils were in Yugoslavia, where, unlike the rest of the Communist Party-led countries, they developed major decision-making powers. In China, in contrast, after the Anti-Rightist campaign of 1957 they became mere window-dressing and eventually atrophied. After Mao's death they were revived under Deng Xiaoping. A State Council proclamation in 1980 announced that they should be established in all enterprises, to provide some offsetting leverage vis-à-vis the new discretionary powers that were being proposed for managers. ${ }^{28} \mathrm{~A}$ congress holds the power - at least on paper - to examine the enterprise's major strategic policies, especially those related to the fate of the enterprise, such as ownership restructuring, merging with other firms or declaration of bankruptcy. ${ }^{29}$ It is also supposed to have the power to reject the appointment of a new manager or to recommend the dismissal of a sitting one, and to have a say on wages, on industrial safety issues, on employee welfare programs and on housing. ${ }^{30}$

28 This was in the State Council-issued "Report on the Pioneering Program on the Expansion of Enterprise Autonomy and Plans for the Future", 1980. A former Chinese trade-union researcher has called the 1980s the "golden age" of the staff and workers representative congresses. Jiang Kelin, "Gonghui yu dang-guojia de chongtu: bashi niandai yilai de Zhongguo gonghui gaige" (The Conflicts between the Trade Union and the Party-state: The Reform of the Chinese Trade Union in the Eighties), Xianggang shehui kexue xuebao (Hong Kong Journal of Social Sciences), No. 8 (Autumn 1996), p. 128.

These rights were codified in Article 52 of the Enterprise Law of 1988.

30 The legal status of the Staff and Workers' Representatives Congress (SWRC) was guaranteed in the Enterprise Law passed in 1988 after the national union federation (ACFTU) lobbied to have this inserted into the law, but the Enterprise Law was applicable only to state and collective enterprises (Jiang Kelin, "Gonghui yu dang-guojia de chongtu"). Once enterprises were transformed into other types of ownership they came under the Company Law passed in 1993. In the newly revised Company Law that went into effect as of January 2006, the ACFTU succeeded in strengthening the legal powers of 
In reality, few of these enterprise staff and workers congresses have ever had the wherewithal to exercise most of their putative rights. In fact, during the course of the 1990s, fewer of them were called into session, as the power of managers expanded and as more state enterprises plunged into the red, slashed employee benefits and downsized their workforces. But the congress continued to exist, even if inactively, at 92 per cent of the state enterprises surveyed in $1997,{ }^{31}$ and in some parts of China they remained active. In 1998 in Liaoning Province, more than 2,300 managers of state-owned enterprises were dismissed or demoted after failing to obtain the necessary 60 per cent of the votes from their enterprise's congress. ${ }^{32}$ At some enterprises where management is corrupt, members of the congresses have taken matters into their own hands, calling themselves into session in attempts to forestall the sale of enterprise assets, to block the enterprise's privatization or even to dismiss the managers. ${ }^{33}$ At one such factory, rebellious congress members declared the factory a "family compound" (jia yuan 家园) that they were defending against "corrupt elements".34

At a large number of state enterprises that have maintained good management-employee relations, the congresses have continued to meet once or twice each year, and they are reported to have some influence vis-à-vis employee welfare policies, housing, and occupational health and safety. ${ }^{35}$ On many other

the SWRC at state enterprises and extending its legal, though not mandatory, existence to enterprises that are not state-owned or dominated by state shares.

31 The figure of 92 per cent was derived by Xiaoyang Zhu and Anita Chan from the raw data of a large nationwide survey sponsored by the All-China Federation of Trade Unions in 1997. Xiaoyang Zhu and Anita Chan, "The Institutionalization of Workers' Articulated Interests”, Chinese Sociology and Anthropology, Vol. 37, No. 4 (Summer 2005), pp. 6-33.

32 China News Digest, 1 June 1998, citing an article in China Daily. In the same year, in the city of Tianjin 660 state-enterprise managers were sacked and another 1,550 enterprise officials were demoted or transferred after receiving less than 50 per cent support in a congress vote of confidence. Gongren ribao (Workers Daily), 10 April 1998.

33 A much-publicized case in the Chinese news media was a paper mill in the city of Zhengzhou, where workers themselves convened a congress to gain control of the mill from corrupt management, after the workers discovered that the managers were assetstripping and enriching themselves in the process. The struggle lasted a few years, and in the end the workers got back their factory, despite an ambivalent, wavering attitude taken by the local government. A local government official has admitted that, once this case set a precedent, some 20 other such cases erupted in Zhengzhou over the following several years. On this Zhengzhou case, see Xiaoyang Zhu, "Misreading' of the Law and 'Imagined Home' in Z Factory", and Tong Xin, "The Cultural Basis of Workers' Collective Action in a Transitional State-Owned Enterprise During a Time of Transition", both in Chinese Sociology and Anthropology, Vol. 38, No. 1 (Winter 2005), pp. 3-41, pp. 4270; also Feng Chen, "Privatization and its Discontents in Chinese Factories", The China Quarterly, No. 185 (March 2006), pp. 42-60.

34 Xiaoyang Zhu, “'Misreading' of the Law”.

35 This is a finding of the survey analysis by Xiaoyang Zhu and Anita Chan, "The Institutionalization of Workers' Articulated Interests". 
policy issues, congress representatives at the distillery have felt that they are out of their depth. A congress was convened there about once a year during the $1990 \mathrm{~s}$ and early $2000 \mathrm{~s}$, but these meetings normally did not have any effect on the management's plans. As an interviewee explained,

At ordinary times, for things not considered particularly important to people, congress members just let the leadership get on with it. The congress sessions let people hear a bit about policies and express their opinions, even though the opinions were not very useful, since the lower levels normally need to listen to the upper levels. Ordinary workers don't know the entire situation, after all; they only know their own patch. This makes most congress meetings formalistic. But when there's a serious matter at stake, in a case like the distribution of new apartments in 1994, which appealed to the direct interests of the staff and workers, then the representatives want to express their opinions.

The staff and workers representative congress decided that the best apartments, at the lowest price, were to be sold to the employees who had worked there the longest, almost all of whom were blue-collar workers. ${ }^{36}$

\section{Debating the Japanese and American Models}

The distillery moved in the direction of the organization-oriented model for reasons intrinsic to its own circumstances. Even if the Japanese/German model did not exist internationally as an example of successful capitalism, it is highly likely that the distillery would have taken the path it did. The question arises, though: were the Chinese aware of the similarities in many of the practices of a Japanese core enterprise and those that were developing at Chinese enterprises like the distillery? In fact, it was a matter for considerable discussion in China, and possibly helped justify, in the eyes of Chinese policy-makers, the course taken by enterprises kindred to the distillery.

From the early 1980s up through the early 1990s, Chinese authors who specialized in industrial policy-making debated the relative value of the contrasting Japanese and Anglo-American corporate models, and up through the early 1990s they exhibited more interest in the Japanese system. At the time, Japan's industrial surge was still being referred to around the world as an "economic miracle". So shifting China's state-owned enterprises in the direction of the Japanese model seemed a means to achieve efficient production and technological progress while avoiding what were considered to be undesirable aspects of market capitalist organization. We have looked through all of the issues for the period between 1980 and 1990 of the Chinese journal Industrial Enterprise Management (Gongye qiye guanli 工业企业管理), and 202 articles were published in it about Japanese enterprises compared to only 122 articles

36 Jonathan Unger and Anita Chan, "The Internal Politics of an Urban Chinese Work Community", pp. 12-14. 
regarding American enterprises. ${ }^{37}$ There was extensive discussion about creating an "enterprise culture" (qiye wenhua 企业文化) at the Chinese workplace, an expression borrowed from Japanese, where it refers to a corporation's efforts to create a harmonious collectivist work environment and a sense of corporate loyalty. ${ }^{38}$

In the latter half of the $1980 \mathrm{~s}$, the distillery was directed to send one of its personnel to receive training organized by the city government in how to implement an explicitly Japanese-style system of Total Quality Control (TQC) at the distillery. He recalls what he learned:

In 1987, all of China was studying Japan's TQC. There were two schools of thought about management. One school saw people as good, and Japan's TQC essentially emerged from this perspective, which was to stimulate people's feelings of self-respect and of pride in their achievements. The other school of thought saw human nature as intrinsically bad, and that was exemplified by Taylorism, in which you needed to use every kind of system of regulations to manage workers, with disciplinary penalties. At that time China turned toward Japan's type of thinking and so turned toward the use of TQC.

But the central government's preferences began shifting progressively away from such thinking from the early to mid-1990s onward. The Japanese model was coming under serious challenge in Japan itself during the 1990s, at a time when the economy was faltering. Most large Japanese firms resisted changing the model significantly during the 1990s and kept their permanent workforces largely intact $^{39}$ but starting in the 2000s major Japanese companies have increasingly pushed in the direction of American-style business practices, focusing on sharemarket values, disbursing large executive bonuses and stock options, and showing reduced attention to the interests of employees. ${ }^{40}$ (Whether the recent melt-downs

37 On this interest in Japanese enterprise management techniques, see also Glen Lewis and Wanning Sun, "Discourses about 'Learning from Japan' in Post-1979 Mainland Chinese Management Journals", Issues and Studies, Vol. 30, No. 5 (May 1994), pp. 63-76.

38 An analysis of the term qiye wenhua that is quite different to ours is contained in Colin Hawes, "Representing Corporate Culture in China: Official, Academic and Corporate Perspectives", The China Journal, No. 59 (January 2008).

39 Kathleen Thelen and Ikuo Kume, "The Future of Nationally Embedded Capitalism: Industrial Relations in Germany and Japan", and Steven K. Vogel, "The Re-Organization of Organized Capitalism: How the German and Japanese Models are Shaping their Own Transformations", both in Kozo Yamamura and Wolfgang Streeck (eds), The End of Diversity?, pp. 194 and 316-7; also Ronald Dore, Stock Market Capitalism, pp. 104-10. The Japanese system even demonstrated considerable resilience to the penetration of the Anglo-American model in Japanese companies recently acquired by foreign capital. George Olcott, "The Impact of Foreign Ownership and Control on Japanese Organisations", PhD dissertation, University of Cambridge, 2005.

40 Personal communication from Ronald Dore, May 2009. 
and discrediting of management practices in the Anglo-American banking and auto industries will cause any rethinking in Japan is, as yet, an open question.)

In China, where economists schooled in America have helped set the tone in government think-tanks, a strong advocacy group emerged in the 1990s in favor of abandoning the elements of Chinese enterprises that are in accord with the Japanese model and of shifting instead wholeheartedly in the direction of American-style firms. Such thinking permeated many of the policy recommendations and directives that the distillery received from the government during the late 1990s and the first decade of the 2000s. These sought to initiate a shift away from life-time employment through the inauguration of fixed-term contracts, insisted that state enterprises dissociate themselves from employees' housing and other non-workplace benefits, and transferred some other welfare functions, such as responsibility for pensions and medical coverage, from the workplace to the government. All of these measures were supposed to draw the Chinese system more towards the Anglo-American model.

Nonetheless, the government has not accepted the Anglo-American model lock, stock and barrel. ${ }^{41}$ As one example, in 1996 the government decided to experiment with the “main bank" (zhuban yinhang 主办银行) system borrowed from Japanese corporate governance. A state enterprise or state-dominated shareholding corporation was to be linked to a bank that was to be responsible for its financing and that would simultaneously monitor its performance. ${ }^{42}$ When the distillery built a large compound of new factory buildings in 1997 to quadruple its production capacity, it turned entirely to its partnered bank, similar to the ongoing relationship between banks and German and Japanese firms, instead of relying on the stock market for new capital. As a second example, the government passed a new contract law in 2007 that re-introduces greater job security and indeed tenure after ten years of employment.

In the toing and froing at the national level between policies that favored the Anglo-American system and those that favored the organization-oriented model, the distillery implemented the former types of policies reluctantly and with delays, and quietly provided extra coverage to employees wherever the new program provided less favorable terms than the enterprise had. This was evident with the government's decisions to remove responsibility for pensions and medical coverage from the hands of workplaces. The government acted because many of the state enterprises were no longer in a financial position to provide these, but the distillery was generously providing both types. The distillery's union chair therefore noted that when the government took over medical coverage at the distillery in 2003, "Workers were worried about it, so we decided to add an extra 160 yuan a month to their pay to compensate. The proposal was to add an equal

41 On Kit Tam, The Development of Corporate Governance in China (Cheltenham: Edward Elgar, 1999), p. 24.

42 On Kit Tam, "Models of Corporate Governance for Chinese Enterprises", Corporate Governance, Vol. 8, No. 1 (January 2000), pp. 91, 93-94. 
amount for everyone. There was a lot of discussion and in the end it was changed to a system based on how many years you'd been with the enterprise."

Similarly, old-age pensions had until recently derived entirely from the distillery's own budget, but the government in 2003 took over the payment of pensions. ${ }^{43}$ Again, the new scheme benefited the employees of a lot of other state enterprises, but it was not popular among the distillery's employees and retirees. They preferred the warm relationship that came with being dependants of their distillery, rather than having to deal with an impersonal government pension office. The 70-year-old head of the retirees' Party group told us early in 2003, "Some retirees fear that once their pensions come from the government and not from our enterprise, the enterprise won't care for us. I tell them that's not possible, the enterprise will still be concerned about (guanxin 关心) us, it will still distribute gifts to us."

\section{Privatizing the Enterprise}

Generally, the largest profitable enterprises remain today under direct public ownership, control and direction under a central government policy to retain the large and release the small (zhua da, fang xiao 抓大, 放小). In line with this policy, starting in the latter part of the 1990s and accelerating in the early 2000s, great numbers of the smaller state enterprises have been restructured, marketized and converted into listed shareholding corporations - though sometimes with a majority share of state ownership. ${ }^{44}$ As a result, as of 2007 only 20,680 industrial firms were state-owned or majority-controlled, and of these only 10,074 industrial enterprises remained entirely state-owned. ${ }^{45}$ The other, smaller enterprises have been entirely or largely privatized, often through management buyouts or management-employee buyouts or as joint ventures with foreign investors. Nevertheless, a portion of these privatized state enterprises have retained the

43 In some other parts of the country, for example Guangdong Province, state enterprises adopted such policies considerably earlier, in the mid- to late 1990s. Ching Kwan Lee, "From Organized Dependence to Disorganized Despotism: Changing Labour Regimes in Chinese Factories", The China Quarterly, No. 157 (March 1999), pp. 44-71.

44 Jean Oi, "Patterns of Corporate Restructuring in China"; Ling Liu, China's Industrial Policies and Global Business Revolution: The Case of the Domestic Appliance Industry (London: Routledge, 2005); Ross Garnaut, Ligang Song and Yang Yao, "Impact and Significance of State-Owned Enterprise Restructuring in China", The China Journal, No. 55 (January 2006), pp. 32-54; Shahid Yusuf, Kaoru Nabeshima and Dwight H. Perkins, Under New Ownership: Privatizing China's State-Owned Enterprises (Washington: The World Bank; Stanford: Stanford University Press, 2006); Le-yin Zhang, "Market Socialism Revisited: The Case of Chinese State-Owned Enterprises", Issues and Studies, Vol. 42, No. 3 (2006) pp. 1-46.

45 Zhongguo tongji nianjian 2008 (China Statistical Yearbook 2008) (Beijing: Zhongguo Tongji Chubanshe), pp. 496, 485. 
attributes of a state enterprise in terms of management style, labor relations and employee benefits. $^{46}$

In 2003, in response to the central government's program, the distillery undertook an MBO (management buy-out of the company's assets). Such buyouts were becoming increasingly common, to the point that the headline in the city's newspaper in January 2003 proclaiming the distillery's imminent privatization simply used those three English letters "MBO" instead of the equivalent Chinese characters, as if most newspaper readers would instantly recognize the English-language acronym for a management buy-out.

To make the MBO seem more palatable, it was in the form of an EMBO (employee-management buy-out). In reality, though, the ordinary employees were restricted to a maximum of only 13 per cent of the enterprise's shares (we were told that this upper limit of 13 per cent was imposed by high-level regulations), and this amount was pulled out of their pension funds. The enterprise trade union head (who is appointed by the distillery's management) would represent their shares on the board of directors. The top 28 managers acquired the great bulk of all the shares at an artificially low price, making use of a massive bank loan. The deputy director of the distillery, who oversaw the buyout, and who seems to us to have the least empathy of any of the managers toward the employees, used the fig leaf of the EMBO to justify what was essentially a management buyout-mouthing phrases like "enterprise culture" and "family" that China had borrowed from the Japanese model. He told us,

If the state sold the property to foreign or domestic capitalists, our corps of employees would feel threatened, because our enterprise culture is not the same as other enterprises'. Our people feel the distillery is their family, a family created by them. The enterprise's national reputation was created by them. So the state, in order to stabilize the feelings of the staff and workers, decided not to sell it to outsiders. The employees would be angry, and this would affect production. It was decided to persuade the employees to raise the capital themselves to buy shares from the state, to buy what they themselves had created.

In order officially to go forward with the MBO, a Staff and Workers Representative Congress meeting was called into session in mid-2003 to approve it. But the meeting was controlled from above. Documents were handed out, and a report on the privatization proposal was read out, but the procedures were so complex that the congress members felt out of their depth and said little. They trusted the general manager, and accepted without questioning that they themselves would only be able to purchase a few stocks. They did not demand a

46 A study of management style, labor relations and employee benefits at two large former state firms - in particular through the prism of medical benefits and occupational safety issues - is Meei-Shia Chen and Anita Chan, "Salvaging China's State Enterprise Industrial Health and Safety Model: Implications for the Future", International Journal of Health Services (forthcoming, 2009). 
right to buy a bigger share, even though this might conceivably make them rich. What instead concerned them was whether the benevolent, paternalistic ethos would continue as before. Questions at the meeting revolved around personal worries over how the buy-out would affect their various perquisites and entitlements. The privatization of their enterprise was approved by a show of hands without any real discussion or dissent.

Even after its privatization, the enterprise continued to provide employees and retirees with gifts, subsidies and other benefits: the organization-oriented model remained alive and well. The distillery did move to implement two major changes, though. First, as the distillery prepared to privatize, it sought to eliminate overemployment by inducing many of the older employees to take early retirement. The distillery targeted women over the age of 43 and men over 48, "though if they have technical skills they don't have to go". Ostensibly, retirement was voluntary, but in reality it was not. These early retirements were part of a nationwide program for firms that were being restructured or privatized, but the distillery insisted on providing higher compensation than necessary. A government directive stipulated that the compensation should be 600 yuan for every year of prior employment but, as a retiree observed, "our distillery fought for a higher sum and provided 1,400 yuan for each year, and a minimum of 10,000 yuan". In addition, the distillery offered a monthly stipend of about 1,000 yuan, plus continued access to some of the perquisites they had enjoyed. If they took up new employment after their early retirement, moreover, it would not affect their stipend and benefits. All the employees we spoke with who had been told to leave were more than willing to go.

The second major change involved the wage system. After the early retirees had departed, in 2004 the distillery declared (again in accordance with announced government preferences) that wages would no longer in part be determined by longevity of employment. Instead, henceforth the rank and post of an employee would play a more important role. Even so, what is most noticeable about the new wage system adopted in 2004 was that (1) egalitarian bonuses remained in place and (2) the salary gap between different types of jobs continued to be quite narrow. In addition, to kick off the new system the distillery raised the incomes of all of the remaining employees, so as to retain a consensus harmony and feelings of "fairness" among the workforce.

Four-and-a-half years later, in May 2009, the distillery continues to look after the workforce in material terms. The year-end bonuses have been retained and, in a still-egalitarian mode, all of the workers on the same shop floor continue to receive the same amount as their mates. Some of the various small subsidies, such as for reading materials and heating, have been dropped within the past couple of years; but even earlier in the decade a number of these petty subsidies had already been considered a bit odd by all but the oldest employees. Some of the other subsidies and gestures of solicitude have remained in place. As one example, the distillery provides a 200-yuan monthly subsidy for each retiree to top up the retirement benefits that they now receive through government channels, and 
enterprise leaders continue to host a restaurant banquet for all the retirees at Chinese New Year.

In other ways, too, elements of the previous enterprise model persist. The staff and workers representative congress continues to exist, and at its 2009 sessions it approved new members for the enterprise's supervisory board and, among other things, also designated several employees as labor models. The trade union still serves as a welfare arm of the enterprise, and enterprise union officials still visit the ill and appraise their needs, organize community activities at the national holidays, distribute gifts of good liquor at Chinese New Year and participate in funerals.

At the same time, the distillery management has done very well out of the privatization. Through the dividends they enjoy, the gap in income between them and ordinary employees has greatly widened. Of the distillery's net profits in 2008, 82.5 per cent were distributed as dividends, resulting in a far lower rate of reinvestment than in previous times. The enterprise's general manager - the one who was greatly trusted by employees - owns 20 per cent of all the shares, and he has very quickly become a very wealthy man. Over the past five years, he has received 97,000,000 yuan (US\$14,000,000) in dividends. But he is careful to remain low-key in his lifestyle, and continues to drive a modest car. ${ }^{47}$

To date, other than the huge financial gains of the top managers, the distillery has not shifted away greatly from previous practices. In light of this, even though the public discourse today in China often assumes that the Anglo-American model is best for China, it is not clear that companies like the distillery will evolve in that direction. A study of Sino-German joint ventures, for instance, finds that a mentality similar to what we described for the distillery persists at these jointventure firms, which had previously been state enterprises. Managers there have to accommodate employees' expectations that the workplace is an "enterprise family", that managers should go on home visits when employees fall sick, and that the personal matters of even laid-off staff should be well taken care of. ${ }^{48}$

Nonetheless, the Chinese government's implementation of privatization and the main thrust of its other policies largely favor the dominance of the AngloAmerican model of capitalism. ${ }^{49}$ There is a strong pull in China among the managerial/ownership class toward self-enrichment, and it appears that, in the service of this, in many of the prosperous former state enterprises and even in some of the remaining major state-owned enterprises workers' conditions are being squeezed, their entitlements to job security undermined and the

47 The information in this paragraph derives from a web-based Chinese-language financial newspaper, 9 May 2009.

48 Monika Schaedler, "Human Resource Management in Sino-German Joint Ventures in China: Building for the Future", in Leo Douw and Kwok-bun Chan (eds), Conflict and Innovation: Joint Ventures in China (Leiden: Brill, 2006).

49 Joel Andreas, "Changing Colours in China", New Left Review, Vol. 54 (November 2008), esp. pp. 131-34. 
organization-oriented model dismantled. Even so, the overall picture is complicated. There are signs that some of the huge state-owned firms have retained practices inherited from the past and have given these an organizationoriented twist-and that an "enterprise culture" persists similar to what we discovered when we were at the distillery.

In several interesting cases, even some private enterprise owners have moved on their own initiative to introduce an organization-oriented model into their companies. A research project examining private enterprises in Zhejiang Province in the late 1990s found that such private firms were usually larger and quite profitable. The owners adopted the organization-oriented system as a means to cultivate the loyalty of their employees. They paid employees quite generous bonuses, provided training for them, and organized social and entertainment programs, all in line with the organization-oriented model. ${ }^{50} \mathrm{~A}$ more recent study conducted by another researcher at a private firm in Zhejiang found an effort to cultivate an "enterprise culture" in order to create a collectivist élan, urging workers to work hard for the "enterprise family". In return, workers enjoy above average conditions, including, for instance, 3,500 yuan worth of gifts to each employee each year, again in line with the organization-oriented style of management. ${ }^{51}$ At two other large private companies in Zhejiang studied by Calvin Chen, ${ }^{52}$ each with about 15,000 employees, the owners rediscovered the usefulness of the Chinese state-enterprise management model after they experienced workers' resistance to their formerly disciplinarian labor regime. At both of these private firms,

Recognizing that profitability could not be earned at the cost of workplace peace, enterprise leaders are now in the midst of a new phase ... focused more on ameliorating social tensions and social distinctions in the workplace. First, new paternalistic practices have been adopted, extending collective benefits to all members. These benefits often take the form of "red envelopes" [containing gifts of money] handed out during chunjie (Chinese New Year) ... gift items like tea sets, raincoats, and umbrellas ... as well as more substantial retirement and severance packages and, most recently, expanded medical care. Moreover, they have moved to redefine membership in the enterprise community. So long as

50 Xiaohong $\mathrm{Xu}$, Zhongguo siying qiye laodong guanxi lun (On the Labor Relations of China's Private Enterprises) (Hangzhou: Hangzhoushi Xinwen Chubanshe, 1998).

51 Feng Tongqing, "Guojia, qiye, zhigong, gonghui zhijian guanxi de shehui zhuanxian: jiazu qiye chengzhang zhong de zhigong canyu anli yanjiu" (Changing Social Relationships among State, Enterprise, Employees and Trade Union: A Case Study of Workers' Participation in the Development of a Clan-owned Enterprise), in Feng Tongqing (ed.), Zhongguo jingyan: zhuanxing shehui de qiye zhili yu zhigong minzhu canyu (China's Experience: Enterprise Governance and Employees' Democratic Participation in a Transitional Society) (Beijing: Social Science Academic Press, 2005), pp. 295-96.

52 Calvin Chen, Some Assembly Required: Work, Community, and Politics in China's Rural Enterprises (Cambridge MA: Harvard University Asia Center, 2008). 
individual members contribute to the well-being of the enterprise, they are considered part of the enterprise "family" (p. 18) ... This development is particularly striking ... because it highlights the continuing appeal of practices more commonly associated with danwei socialism. This program also works at a symbolic level—activities such as speech and singing contests and sporting events are designed to reinforce the notion that the enterprise is the critical, new locus of identity and interaction where the perspectives and behavior of enterprise members can and will be reshaped. ${ }^{53}$

In these private firms, this effort to focus employees' loyalty toward the enterprise is not, of course, in line with danwei socialism, which was stateoriented. Rather, it is the organization-oriented model that endeavors to spur morale and to retain dedicated employees by creating what the Japanese also refer to as an "enterprise family". The socialist danwei may look similar, and indeed these private enterprises are adopting some of the measures that had been practiced in danweis. But the essential purpose of these private companies and the intended focus of loyalty are entirely different from what had been promoted in danwei socialism. So too, danwei-like practices that are actually organizationoriented can be found today in China's public-service (shiye 事业) institutions, such as hospitals, universities and the like.

Extensive research over the coming years will be needed to reveal whether the Chinese-style organization-oriented model survives the restructuring processes underway in the state-owned sector, and whether the model survives, too, in the privatized state enterprises and in the entirely private sector of China's economy. But the possibilities are clear, in particular at some of the companies that are making a reasonable profit and can afford to resist lay-offs and cut-backs in employee welfare. The legacy of an "enterprise culture" at the distillery is favorable to such an outcome. Path-dependent development may yet lead to the persistence of an organization-oriented system "with Chinese characteristics" in at least part of the Chinese industrial economy.

53 Calvin Chen, Some Assembly Required, p. 127. 